Available online at www.banglajol.info

Bangladesh J. Sci. Ind. Res. 51(1), 75-80, 2016

\section{BANGLADESH JOURNAL OF SCIENTIFIC AND INDUSTRIAL RESEARCH}

E-mail: bjsir07@gmail.com

\title{
Establishment of in vitro regeneration protocol for Adhatoda vasica Nees.
}

\author{
S. Khan*, S. Akter, A. Habib, T. A. Banu, M. Islam, N. F. Khan, S. Afrin, A. Ferdousi and S. Islam \\ Plant Tissue Culture Section, Biological Research Division, BCSIR Laboratories, Dhaka, Bangladesh Council of \\ Scientific and Industrial Research, Dhanmondi, Dhaka-1205, Bangladesh
}

\begin{abstract}
An in vitro regeneration protocol of Adhatoda vasica has been developed using excised nodal segments and juvenile leaves for multiple shoots regeneration directly or through callus induction. Explants were cultured on MS medium with different concentrations of IAA, NAA, BAP, $\mathrm{GA}_{3}$ and $\mathrm{Kn}$ singly or in combinations. MS medium supplemented with BAP (10.0 mg/l) was found best for multiple shoot formation, in which $93.33 \%$ explants produced multiple shoots. After two months, maximum number of multiple shoots were $10.6 \pm 1.82$, highest length of plantlets was $5.2 \pm 2.20 \mathrm{~cm} .100 \%$ calli formation were observed on MS medium supplemented with IAA $(0.05 \mathrm{mg} / \mathrm{l})+\mathrm{NAA}$ $(0.05 \mathrm{mg} / \mathrm{l})+$ BAP $(1.0 \mathrm{mg} / \mathrm{l})$. Callus initiation started after 14 days and gave light green colored callus. Best callus mediated shoot regeneration was found on MS+10.0 mg/l BAP medium. Root induction of in vitro raised shoots was best on $1 / 2 \mathrm{MS}+\mathrm{IBA}(1.0 \mathrm{mg} / \mathrm{l})$. Well rooted plantlets were transferred to plastic pots containing garden soil and compost in a ratio of 2:1 for hardening. The ultimate survival rate under natural condition was about $80 \%$.
\end{abstract}

Keywords: Adhatoda vasica; Nodal segment; Leaf explants; Multiple shoot; Callus induction.

\section{Introduction}

Adhatoda vasica locally known as "Basak" is a very well known medicinal plant, belonging to the family Acanthaceae. It is an evergreen woody shrub widespread throughout the tropical regions of Southeast Asia, including Bangladesh (Chakrabarty and Brantner, 2001). Adhatoda vasica is a highly reputed plant in Ayurvedic and Unani medicine. Basak leaves have been used extensively primarily for respiratory disorders. It is mainly antispasmodic, fever reducer, anti-inflammatory, anti bleeding, bronchodilator, antidiabetic, antihelminthic, disinfectant, anti-jaundice, antiseptic, oxitocic and expectorant and has many other medicinal applications (Chakrabarty and Brantner, 2001). Most studied phytochemical active compounds in Adhatoda vasi$c a$ are vasicine and vasicinone. It is well established now that vasicine is the major as well as the most important active principle of this medicinal plant (Wasserman and Kuo, 1991). It is reported to be responsible for most of its activities including: antioxidant, anti-inflammatory and bronchodilatory activity. (Amin, and Mehta, 1959; Bruce and Kumar, 1968). Other chemical compounds found in Adhatoda vasica plant includes essential oils, fats, resins, sugar, gum, amino acids, proteins and vitamins ' $\mathrm{C}$ ' etc (Bhat et al., 1978). Additionally, the high phenolic derivative content of essential oils contributes to their antimicrobial properties (Bandini et al., 1981). The roots also contain alkaloids (vasicinal, vasicinolone, vasicinone and adhatonine), a steroid (daucosterol), carbohydrates and alkanes. In the flowers, triterpenes ( $\alpha$-amyrin), flavonoids (Apigenin, Astragalin, Kaempferol, Quercetin, Vitexin) and alkanes have been found (Haq et al., 1967). In Bangladesh, Adhatoda vasica grows as a mixed crop in the rubber garden as well as in the tea garden, on the roadside and fallen lands. Adhatoda vasica shows low seed germination and conventional propagation through cutting is very slow (Gauri and Reddy, 2007). So, the aim of the present study is to develop a suitable in vitro regeneration protocol of Adhatoda vasica Nees.

\section{Materials and methods}

The present experiment was conducted in Plant Tissue Culture Section of Bangladesh Council of Scientific and Industrial Research (BCSIR), Dhanmondi, Dhaka. Fresh young leaves and nodal segments of Adhatoda vasica were collected from the plants grown in the BCSIR research field. The fresh juvenile leave, nodal segments and split nodal halves were then used for callus induction and direct regeneration respectively. Leaves and nodal segments of Adhatoda vasica were taken in a $500 \mathrm{ml}$ conical flask for surface sterilization. These explants were kept under running tap water for 30 minutes, then washed with mild detergent and washed with tap water. After this, the explants were taken into laminar airflow cabinet, added $70 \%$ alcohol for 1

\footnotetext{
*Corresponding author. e-mail: k2salim@yahoo.com
} 
minute then rinsed off with sterile distilled water. Finally added $0.1 \% \mathrm{HgCl}_{2}(\mathrm{w} / \mathrm{v})$ for 5 minutes for nodal explants and 3 minutes for leaf explants with continuous stirring followed by washing 3 times with sterile distilled water. Surface sterilized leaves were cut into small pieces and 3-4 excised pieces were taken into a conical flask containing agar solidified MS (Murashig and Skoog, 1962) medium supplemented with various concentrations of BAP, NAA, $\mathrm{Kn}, \mathrm{IAA}$ and $\mathrm{GA}_{3}$ alone or in combinations for callus induction. All media contained 3\% sucrose and $7.0 \mathrm{gm} / 1$ agar with pH 5.8 adjusted before autoclaving. Green callus was excised and transferred to fresh MS medium containing similar compositions of plant growth regulators for organogenesis. Nodal explants were cut into one single node and inoculated vertically onto test tubes containing shoot regeneration media. In each test tube a single cutting was placed. All in vitro grown cultures were maintained under illumination on a $12 \mathrm{~h}$ photoperiod at $25 \pm 2{ }^{\circ} \mathrm{C}$. Regenerated shoots were subcultured every four weeks on the freshly prepared same medium. When the regenerated shoots were $4-5 \mathrm{~cm}$ in length, they were transferred to freshly prepare medium containing half strength of MS and MS medium with different concentrations of IBA for root induction. Rooted plantlets were transferred to small plastic pots containing sterilized soil and covered with polythene bags to maintain high humidity. After 50 days the acclimatized plants were transferred to larger pots containing garden soil and compost in ratio of $2: 1$ and moist them adequately for proper hardening.

Table I. Effect of different concentrations of phytohormones on direct shoot regeneration from nodal explants of Adhatoda vasica.

\begin{tabular}{|c|c|c|c|c|c|}
\hline $\begin{array}{c}\text { MS+ } \\
\text { Best Supplements (mg/l) }\end{array}$ & $\begin{array}{l}\% \text { of explant } \\
\text { showed } \\
\text { re-generation }\end{array}$ & $\begin{array}{l}\text { Days required } \\
\text { for initiation }\end{array}$ & $\begin{array}{l}\text { Multiple shoot } \\
\text { (mean) } \pm \text { SE }\end{array}$ & $\begin{array}{l}\text { Length of plantlet } \\
(\mathrm{cm}) \pm \mathrm{SE}\end{array}$ & $\begin{array}{l}\text { No. of leaf } \\
\text { (mean) } \pm \text { SE }\end{array}$ \\
\hline 10.0 BAP & 93.33 & 7 & $10.6 \pm 1.82$ & $5.2 \pm 2.20$ & $15.6 \pm 1.80$ \\
\hline $0.5 \mathrm{Kn}+10 \mathrm{BAP}$ & 70 & 10 & $4 \pm 1.45$ & $4.6 \pm 1.80$ & $10 \pm 1.60$ \\
\hline $0.5 \mathrm{NAA}+10.0 \mathrm{BAP}$ & 90 & 13 & $4 \pm 1.60$ & $5 \pm 1.17$ & $14 \pm 1.42$ \\
\hline $0.5 \mathrm{IAA}+8.0 \mathrm{BAP}$ & 86.67 & 19 & $2 \pm 1.65$ & $2 \pm 0.85$ & $12 \pm 1.46$ \\
\hline $0.5 \mathrm{IAA}+9.0 \mathrm{BAP}$ & 86.67 & 19 & $3 \pm 2.10$ & $1 \pm 1.25$ & $14 \pm 1.70$ \\
\hline $0.5 \mathrm{IAA}+10.0 \mathrm{BAP}$ & 86.67 & 19 & $2 \pm 1.84$ & $1 \pm 0.90$ & $12 \pm 1.55$ \\
\hline $0.5 \mathrm{Kn}+0.5 \mathrm{NAA}+8.0 \mathrm{BAP}$ & 90 & 16 & $4 \pm 1.88$ & $2 \pm 1.00$ & $13 \pm 1.43$ \\
\hline $0.5 \mathrm{Kn}+0.5 \mathrm{NAA}+9.0 \mathrm{BAP}$ & 90 & 16 & $5 \pm 2.10$ & $4 \pm 1.90$ & $14 \pm 1.82$ \\
\hline $0.5 \mathrm{Kn}+0.5 \mathrm{NAA}+10 \mathrm{BAP}$ & 90 & 16 & $5 \pm 2.30$ & $4 \pm 1.63$ & $11 \pm 1.60$ \\
\hline $0.5 \mathrm{IAA}+0.5 \mathrm{NAA}+5.0 \mathrm{BAP}$ & 80 & 12 & $5 \pm 1.90$ & $3 \pm 1.33$ & $12 \pm 1.36$ \\
\hline
\end{tabular}

\section{Results and discussion}

In the present study, attempts were made to establish efficient in vitro protocols for large scale production of Adhatoda vasica (Nees) through direct and indirect organogenetic pathways. Direct regeneration and shoot regeneration via callus induction was done with nodal segments and juvenile leaves respectively in this study. MS media in combination with different hormonal supplements namely, IAA, NAA, IBA, BAP, GA 3 and $\mathrm{Kn}$ were used singly or in combinations to observe their effect on multiple shoot development form the shoot tip and nodal segment. Among the media components used in this study MS medium supplemented with BAP (10.0 mg/l) showed best response for multiple shoot formation. In this combination about $93.33 \%$ explants produced multiple shoots (Table I, Fig. 1b). Mean number of multiple shoots $(10.6 \pm 1.82)$, mean length of plantlets $(5.2 \pm 2.20)$ and mean number of leaves $(15.6 \pm$ 1.80) were recorded (Table I, Fig. 1d) after two months. For further multiplication, regenerated shoots were subcultured on the same media. According to Gauri and Reddy (2007), maximum number of shoots $(7.75 \pm 0.392)$ differentiated from split nodal halves on MS medium supplemented with $10.0 \mathrm{mg} / \mathrm{l} \mathrm{BAP}$ during 4 weeks of culture, but these shoots failed to grow upon subculture in the same medium (Gauri and Reddy, 2007). MS medium supplemented with coconut water $15.0 \%$ + BAP (5.0 mg/l) started proliferated multiple shoots of Adhatoda vasica in 3 to 4 weeks and shoots became $3 \mathrm{~cm}$ long in 6 to 8 weeks, was reported best by Raageeva and Shahnawaz (2012). In a comparison of MS media supplemented with BAP (6.0-10.0 mg/l), it was found that MS $+10.0 \mathrm{mg} / \mathrm{l}$ was the best media for shoot elongation (Fig. 1c). $\mathrm{MS}+$ 

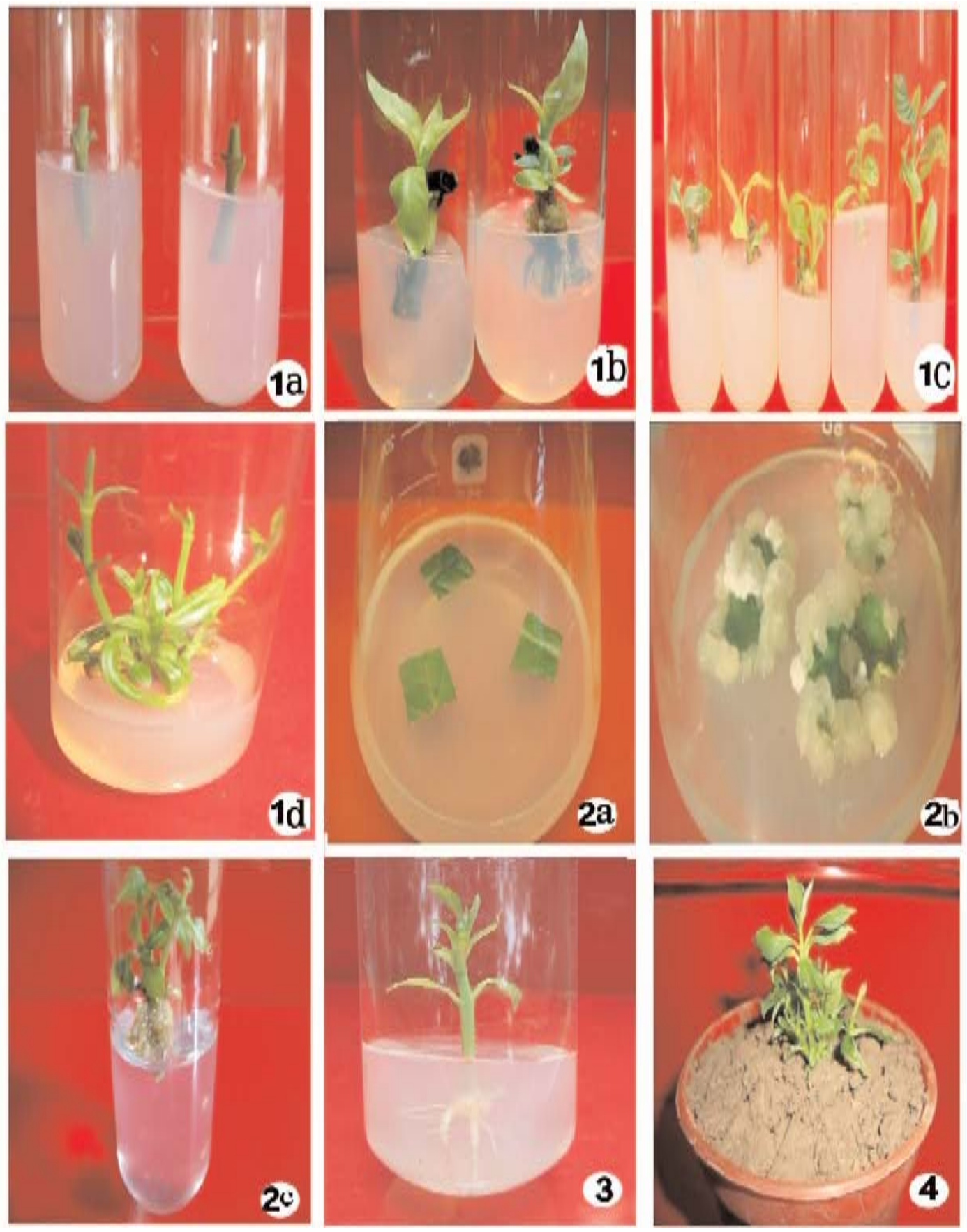

Fig. 1-4. Steps involved in regeneration of Adhoatoda vastca from nodal and leaf explants. 1a. Stem nodal explants. 1b. In vitro regenerated shoots. 1c. Compartive response of $A$. vasica on MS medium supplemented with 6.0, 7.0, 8.0, 9.0 and $10.0 \mathrm{mg} / 1 \mathrm{BAP}$ respectively. 1d. Shoot multiples cation. 2a. Leaf explants for callus induction. 2b. Green callus on MS media supplimented with IAA $(0.05 \mathrm{mg} / 1)+$ NAA $(0.05 \mathrm{mg} / 1)+$ BAP $(1.0 \mathrm{mg} / 1)$. 2c. Multiple shoot regeneration from callus cells. 3. Rooting. 4. Hardened potted plant lets

In case of callus induction, best result was obtained from MS medium containing IAA $(0.05 \mathrm{mg} / \mathrm{l})+\mathrm{NAA}(0.05 \mathrm{mg} / \mathrm{l})+$ BAP (1.0 mg/l) (Table II). 30 explants were inoculated; cal- lus initiation started from 14 days, $100 \%$ explants responded and gave green colour, soft, fast growing callus (Table II, Fig. $2 b)$. Media containing IBA $(1.0 \mathrm{mg} / \mathrm{l})$ with $\mathrm{GA}_{3}(1.0$ 
Table II. Effect of different concentrations of phytohormones on induction of callii from leaf explants of $\boldsymbol{A}$. vasica.

\begin{tabular}{|c|c|c|c|c|c|}
\hline $\begin{array}{c}\text { MS+ Best Supplements } \\
(\mathrm{mg} / \mathrm{l})\end{array}$ & $\begin{array}{l}\text { No. of explants } \\
\text { inoculated }\end{array}$ & $\begin{array}{l}\text { Days required } \\
\text { for initiation } \\
\text { of callus }\end{array}$ & $\begin{array}{l}\text { No. of explants } \\
\text { showed callus } \\
\text { formation }\end{array}$ & $\begin{array}{l}\% \text { of responsive } \\
\text { explants }\end{array}$ & Color \\
\hline $1 \mathrm{BAP}+(5.0 \mathrm{mg} / \mathrm{L}) 2,4-\mathrm{D}$ & 30 & 14 & 26 & 86.67 & Light green \\
\hline $7 \mathrm{BAP}+(2.0 \mathrm{mg} / \mathrm{L}) 2,4-\mathrm{D}$ & 30 & 20 & 28 & 93.33 & White \\
\hline $2.0 \mathrm{Kn}+(3.0 \mathrm{mg} / \mathrm{L}) 2,4-\mathrm{D}$ & 30 & 16 & 26 & 86.67 & Light green \\
\hline $5.5 \mathrm{mg} / \mathrm{L} 2-4-\mathrm{D}+1.0 \mathrm{mg} / \mathrm{L} \mathrm{Kn}$ & 30 & 24 & 20 & 66.67 & Light green \\
\hline $2 \mathrm{mg} / \mathrm{L} 2,4-\mathrm{D}+2 \mathrm{BAP}+2 \mathrm{Kn}$ & 30 & 12 & 18 & 60 & Light green \\
\hline $0.05 \mathrm{IAA}+2.5 \mathrm{GA}_{3}$ & 30 & 23 & 25 & 83.33 & Light green \\
\hline $1.0 \mathrm{mg} / 1 \mathrm{GA}_{3}+0.09 \mathrm{mg} / \mathrm{l} \mathrm{BAP}$ & 30 & 29 & 17 & 56.67 & White \\
\hline $0.09 \mathrm{mg} / 1 \mathrm{GA}_{3}+1.0 \mathrm{mg} / \mathrm{l} \mathrm{BAP}$ & 30 & 19 & 26 & 86.67 & Light green \\
\hline $0.09 \mathrm{mg} / 1 \mathrm{NAA}+1.0 \mathrm{mg} / \mathrm{l} \mathrm{BAP}$ & 30 & 25 & 20 & 66.67 & Light green \\
\hline $0.05 \mathrm{IAA}+0.05 \mathrm{NAA}+1 \mathrm{BAP}$ & 30 & 14 & 30 & 100 & Green \\
\hline $1.0 \mathrm{IBA}+1.0 \mathrm{GA}_{3}$ & 30 & 14 & 28 & 93.33 & Light green \\
\hline
\end{tabular}

Table III. Effect of different concentrations of BAP alone with MS on shoot regeneration via callus formation from leaf explants of $A$. vasica.

\begin{tabular}{lccccc}
\hline Supplements $(\mathrm{mg} / \mathrm{L})$ & $\begin{array}{c}\text { \% of explant showed } \\
\text { re-generation }\end{array}$ & $\begin{array}{c}\text { Days required } \\
\text { for initiation }\end{array}$ & $\begin{array}{c}\text { Multiple shoot } \\
(\text { mean }) \pm \text { SE }\end{array}$ & $\begin{array}{c}\text { Length of plantlet } \\
(\mathrm{cm}) \pm \text { SE }\end{array}$ & $\begin{array}{c}\text { No. of leaf } \\
(\mathrm{mean}) \pm \mathrm{SE}\end{array}$ \\
\hline 5.0 BAP & 40 & 21 & & & \\
6.0 BAP & 50 & 17 & $2 \pm 0.30$ & $1.7 \pm 0.52$ & $7 \pm 0.63$ \\
7.0 BAP & 40 & 19 & $2 \pm 0.55$ & $2.0 \pm 0.83$ & $6 \pm 0.87$ \\
8.0 BAP & 60 & 16 & $3 \pm 0.90$ & $2.5 \pm 0.95$ & $7 \pm 1.13$ \\
9.0 BAP & 60 & 12 & $4 \pm 1.20$ & $2.7 \pm 1.07$ & $8 \pm 1.26$ \\
10.0 BAP & 80 & 10 & $4 \pm 1.70$ & $3.0 \pm 1.56$ & $11 \pm 1.45$ \\
\hline
\end{tabular}

$\mathrm{mg} / \mathrm{l})$ also showed better reponse, callus initiation started from 14 days, 93.33\% of responsive explants gave light green colour callus (Table II). Whereas, Renu, and Nidhi (2011), got best result for callus induction after using NAA $(2.5 \mathrm{mg} / \mathrm{L})$ in combination with BAP $(0.5 \mathrm{mg} / \mathrm{L})$. Callus formation was observed after 15 and 21 days, respectively by Sunita and Dhananjay (2010) using MS media supplemented with various combinations of auxin and cytokinin.

Green and light green callii were transferred on MS medium supplemented with BAP (0.5-10.0 mg/1) for callus mediated shoot regeneration. Best result was found from $\mathrm{MS}+10.0$ mg/l BAP medium (Table III, Fig. 2c). Callus mediated shoot regeneration of Adhatoda vasica was not reported by other researchers. Most of them used callus for isolation of alkaloids (Sunita and Dhananjay, 2010).

After shoot elongation, healthy regenerated shoots from both nodal explants and callus were transferred on MS and $1 / 2 \mathrm{MS}$ media supplemented with different concentrations of IBA for root induction. In the present investigation, $1 / 2 \mathrm{MS}+$ IBA (1.0 mg/l) performed best towards root induction (Table IV, Fig. 3).

After sufficient development of roots the plantlets obtained from Adhatoda vasica were successfully transplanted into small plastic pots containing sand, soil and cowdung (1: 1: 1). The survival rate of the transplanted plantlets was found to be about $80 \%$. Same survival rate of acclimatized plantlets, was also reported (Raageeva \& Shahnawaz, 2012). Following proper acclimatization the plantlets were established in field condition (Fig. 4). The in vitro regeneration protocol described here is easily reproducible, requires minimum hormonal supplements and genotype independent. Moreover, the regeneration of plantlets achieved without the intervention of callus and this clearly indicates the possibility of obtaining true to type plantlets. The technique 
Table IV. Effect of different media and IBA on root induction of in vitro regenerated shoots of $\boldsymbol{A}$. vasica.

\begin{tabular}{lcccc}
\hline Media/Supplements (mg/l) & $\begin{array}{c}\text { No. of explants } \\
\text { inoculated }\end{array}$ & $\begin{array}{c}\text { No. of respon- } \\
\text { sive explants }\end{array}$ & $\begin{array}{c}\% \text { of explants showed } \\
\text { root formation }\end{array}$ & $\begin{array}{c}\text { Days required for } \\
\text { initiation of rooting }\end{array}$ \\
\hline $1 / 2 \mathrm{MS}$ & 10 & 3 & $30 \%$ & 18 \\
$\mathrm{MS}$ & 10 & 3 & $30 \%$ & 15 \\
$1 / 2 \mathrm{MS}+1.0$ IBA & 10 & 8 & $80 \%$ & 12 \\
MS +1.0 IBA & 10 & 6 & $60 \%$ & 14 \\
\hline
\end{tabular}

described here appears to be readily adaptable for mass propagation of Adhatoda vasica.

\section{References}

Amin AH and DR Mehta (1959), A bronchodilato alkaloid (vasicine) from Adhatoda vasica Nees. Nature, 184: 1317.

Bandini P and Pacchiani M (1981), Constituents, properties and use of Calamintha nepeta. Essenze Deriv. Agrum., 51: 325-330.

Bhat VS, Nasavatl DD and Mardikar BR (1978), Adhatoda vasica-an Ayurvedic plant. Indian Drugs, 15: 62-66.

Bruce RA and Kumar V (1968), The effect of a derivative of vasicine on bronchial mucus. Brit. J. Clin. Prac., 22: 289-292.

Chakrabarty A and Brantner AH (2001), Study of alkaloids from Adhatoda vasica Nees on their anti-inflammatory activity. Phytother. Res., 15: 532-534.

Gauri A and Reddy VD (2007), Rapid micropropagation via axillary bud proliferation of Adhatoda vasica Nees. Indian Journal of Experimental Biology, 45: 268-271.

Huq ME, Ikram M and Warsi SA (1967), Chemical composition of Adha-toda vasica Linn. II. Pak. J. Sci. Ind. Res., 10: 224-225.

Murashige T and Skoog FA (1962), Revised medium for rapid growth and bioassays with tobacco tissue cultures. Physiol. Plant. 15: 473-497.
Raageeva B and Shahnawaz M (2012), Plant regeneration from nodal explants of Adhatoda vasica Nees. Journal of Medicinal Plants Research 6(7): 1229-1233.

Renu S and Nidhi B (2011), Impact of growth regulators on callus production of two medicinal plants viz. Adhatoda vasica and Ageratum conyzoides. International journal of research in plant science, 1(1): 1-8.

Sunita M and Dhananjay S (2010), In vitro Callus Culture of Adhatoda Vasica: A Medicinal Plant, Annals of Biological Research, 1 (4): 57-60.

Wasserman H and Kuo GH (1991), The chemistry of vicinyl trycarbonyl, an efficient synthesis of -Vasicine. Tetrahed. Lett., 32: 7131-7132.

Received: 10 September 2013; Revised: 01 January 2015; Accepted:19 October 2015. 